\title{
CEO Characteristics and Real Earnings Management in Jordan
}

\author{
Mohammad Abedalrahman Alhmood ${ }^{1}$, Hasnah Shaari ${ }^{1} \&$ Redhwan Al-dhamari ${ }^{1}$ \\ ${ }^{1}$ Tunku Puteri Intan Safinaz School of Accountancy, Universiti Utara Malaysia, Sintok, Malaysia \\ Correspondence: Mohammad Abedalrahman Alhmood, Tunku Puteri Intan Safinaz School of Accountancy, \\ Universiti Utara Malaysia, 06010 Sintok, Kedah, Malaysia.
}

Received: March 17, 2020

Accepted: May 2, 2020

Online Published: July 7, 2020

doi:10.5430/ijfr.v11n4p255

URL: https://doi.org/10.5430/ijfr.v11n4p255

\begin{abstract}
The Chief Executive Officer (CEOs) tends to be the most influential member of a corporation as they exert control over corporate decisions such as financial disclosure, board structure, and company performance in ensuring enhanced corporate performance and earnings. The issue of earnings management (EM) that has captured the attention of researchers may be among the most critical factors that are linked to financial statement manipulation. Therefore, the current study explored the effects of the personal characteristics of CEOs on real earnings management (REM) practices in Jordan. Data of 58 companies listed on the Amman Stock Exchange for six years from 2013 to 2018 were utilised to achieve this study's objectives. The results of this study revealed that CEOs' experience had a significantly positive association with REM. Meanwhile, CEOs' tenure had no impact on REM among Jordanian firms. Also, the results exposed the presence of a significantly negative association between CEO duality and REM. Finally, CEOs' political connection was found to have a significantly positive association with REM. This study offers empirical evidence on the effect of CEO characteristics on REM and how such characteristics can lead to exploitation, which brings an impact on the financial reporting quality.
\end{abstract}

Keywords: CEO characteristics, real earnings management, Jordan

\section{Introduction}

The collapse of reputable companies like Enron in 2001 and Arthur Andersen and WorldCom in 2002 has raised concerns about the financial reporting integrity and the efficiency of internal control mechanisms (Leventis \& Dimitropoulos, 2012).

Financial statements need to be reliable as they serve as essential sources for decision-making for investors (Liu, 2012; Alsraheen \& Saleh, 2017; Altarawneh, Shafie, \& Ishak, 2020). However, financial scandals have eroded investors' trust in the quality of the information disclosed by listed firms. Thus, users of financial reports have become more sceptical in using financial statements, particularly due to concerns about the quality of these statements following instances of reporting irregularities and the revelation of unacceptable accounting practices even in well-respected companies (Alsraheen \& Saleh, 2017).

Reported earnings are among the most robust details in financial statements and as such, affect the company, investment, and managerial staff decisions. Therefore, company executives might be compelled to change earnings to obtain favourable benefits for themselves (Healy \& Wahlen, 1999). In this case, earnings management (EM) is "any practice that company managers use to report accounting results for opportunistic purposes and/or intelligence purposes which do not correlate to the ones they have accomplished" (Osma, Noguer, \& Clemente, 2005; Bermejo-Sánchez, Rodríguez-Ariza, \& Martínez-Ferrero, 2015). EM often includes the manipulation of accounting data. These manipulations compromise the quality of disclosed earnings and reduce investors' trust in financial reporting (Sáenz González \& García-Meca, 2014; Saleem, Alifiah, \& Tahir, 2016).

While the financial world has been rocked with headline-grabbing stories of corporate failures, Jordan has witnessed its share of corporate scandals which, in turn, creates the need for enhanced corporate governance. Jordan has experienced several financial collapses, such as the events of Petra Bank in 1989 and Shamayleh Gate in 2002 (Jordanian Forum for Economic Development [JFED], 2003). In particular, the Shamyaleh Gate event had cost Jordanian banks more than USD1 billion, thus attracting attention to corporate governance (JFED, 2003). As a result of this event, Jordan experienced a serious financial crisis which led to business failures and a decline in the Jordanian Dinar (JD) exchange rate from USD 3.35 in 2006 to USD 1.41 in June 2008 (Alawaqleh, 2008; Shbeilat, 
2013). The crisis has attracted the attention of policymakers and led them to support corporate governance standards and the importance of external auditors to the Jordanian economy (Zureigat, Fadzil, \& Ismail, 2014). Following the corporate scandals in Jordan and the rest of the world, the function of corporate governance has become noticeable in monitoring and controlling the work of executives around the globe and in the Arab world (Ramadan, 2016).

The part of the Chief Executive Officer (CEO) in the abuse of accounting and financial reporting has long been reported. The report of the Treadway Committee of Sponsoring Organizations (COSO, 1999) revealed that in 83\% of the fraud cases since 1987, either the CEO or the Chief Financial Officer (CFO) was directly involved in frauds. CEOs have been embroiled in financial statements misconduct since 1999. For example, after the disclosure of manipulation of earnings by CEO Kozlowski in 2002, Tyco lost its market value of USD 100 billion, which exceeded the total loss incurred by Enron (Troy et al., 2011).

The CEO is viewed as the most influential member of a corporation as they exert control over corporate decisions such as financial disclosure, board structure, and corporation performance. Their obligation towards stakeholders pertaining to corporate performance tends to lead to the management of earnings (Chou \& Chan, 2018).

Upper echelons theory has raised many debates on the demographic characteristics of the top management team. This theory's core concept is that the organisation represented by its CEO (Hambrick \& Mason, 1984). This theory also believes that CEOs' characteristics influence their choices. Furthermore, upper echelons theory discussed that due to their personal characteristics and unique skills, CEOs affect the development of values, strategic decisions, and company reporting decisions (Hambrick \& Mason, 1984). Moreover, this theory says that the CEO's temperament, experience, and beliefs affect their premeditated decisions by interpreting the circumstances they face (Hambrick, 2007).

Besides, agency theory expects that managers are motivated to achieve their benefits at the expense of stockholders' interests (Jensen, 1986). The interaction between a CEO's attribute and EM needs more examination (Chou \& Chan, 2018). The existing literature provides ample evidences about the impact of the CEO's experience on EM, either positively (Zhao et al., 2016; Matsunaga \& Yeung, 2008; Ran, Fang, Luo, \& Chan, 2015; Schrand \& Zechman, 2012) or negatively (Troy et al., 2011; Jiang, Zhu, \& Huang 2013).

Carroll and Negro (2014) examined the impact of the top management structure and procedures on organisational outcomes and the influence of the CEO's characteristics on business strategy. Several researchers proposed that critical demographic issues (e.g., age, education, experience, and gender) play a role in the top-level management's connection to fraud (Greve, Palmer, \& Pozner, 2010; Hambrick, 2007; Schrand \& Zechman, 2012; Zahra, 2005; Troy et al., 2011). Thus, the current study investigated the relationship between CEOs' characteristics and EM in Jordan.

\section{Literature Review and Hypotheses Development}

\subsection{CEOs' Experience}

A CEO's financial knowledge is essential in assessing the reliability of financial statements. CEOs are likely to learn more about financial and accounting issues from their management skills and experience in their fields, make reasonable accounting judgements, and enhance the financial reporting structure (Gounopoulos \& Pham, 2018). CEOs with financial expertise are also conscious of the sort of information investors need from the comprehensive financial market knowledge and the value of accounting information for investors (Custódio \& Metzger, 2014; Gounopoulos \& Pham, 2018).

Prior studies have explained about how the CEO's experience and perceptions can affect organisational decisions. In reality, the degree and form of work experience influence the CEO's cognitive structure, strategic options, and decision-making models or processes (Hitt \& Tyler, 1991). Managers with excellent skills have more social resources and functional learning capabilities in addition to a robust selection of analytical skills (He et al. 2015). Therefore, they may engage in a financial report using their professional judgement or the design of actual transactions to modify accounting information (Zhao, Gao, \& Wang, 2016).

$\mathrm{Hu}$, Huang, Li, and Liu (2017) conducted that companies whose CEOs came from a financial background had low accountability. Previously, Kouaib and Jarboui (2016a) investigated the connection between the CEO's profile and REM in European companies using data from 190 European companies and 460 CEOs. Their study has shown a significantly positive relationship between CEOs' experience and REM.

In addition, Custódio and Metzger (2014) found that expert CEOs tended to convey accounting information more efficiently to the public as they understood the value of information in shaping investors' assessments. Furthermore, 
Ran et al. (2015) found that executives from the accounting and financial background could identify and correct financial fraud and EM behaviour immediately and increase the comprehensiveness, fairness, and reliability of accounting information reporting, thus enhancing the quality of accounting information of the organisation. Likewise, Gounopoulos and Pham (2018) found evidence suggesting the role of CEOs with financial experience in reducing EM among the United States (U.S.) listed firms. Moreover, Schrand and Zechman (2010) revealed that experienced CEOs were more willing to take risks than those who were less experienced. In comparison, Troy, Smith, and Domino (2011) analysed the impact of CEOs' experience on accounting fraud and found a significant negative connection between CEOs' experience and EM.

Jiang, Zhu, and Huang (2013) investigated how financially experienced Chinese CEOs engaged in more or less EM than CEOs without experience. Their study, using the data of listed Chinese firms from 2002 to 2008, showed that financially experienced CEOs tended to avoid being involved in real EM practices. The findings suggest that financially experienced CEOs provide more reliable earnings and financial statements. Thus, the following hypothesis is posited:

$\mathrm{H}^{1}$ : CEOs' experience is related to REM among Jordanian companies listed on ASE.

\subsection{CEOs' Tenure}

EM by CEOs in their first and last years as CEOs has been the subject of intense discussions in previous literature works. Such findings revealed a correlation between new CEOs and non-routine adjustments in their first year of service concerning excess expense and loss to delegate those expense and loss to the former CEOs, where they then claimed credit for better earnings in the next few years (Ali \& Zhang, 2014).

Previous studies found that CEOs overestimated the previous year's earnings; nevertheless, the existing empirical evidence shows mixed results (Ali \& Zhang, 2014). Other researchers found new relationships between EM and CEOs' tenure. For example, Di Meo (2014) examined a sample of US companies from 1992 to 2011 and found that CEOs with a long tenure adopted an opportunistic behaviour through EM to conceal investment inefficiencies.

Some studies have compared EM between the CEOs' early and late years. Hu et al. (2015), for example, observed the effect of CEOs' tenure on EM. Their study on the Chinese stock market data between 2003 and 2005 found that managers were cautious when they first assumed top management positions, and then they became more aggressive in the subsequent years. When they hit the highest level of EM, they were again cautious and reported less aggressively on earnings.

Ali and Zhang (2014) found a significantly positive link between CEOs' tenure and EM. Kouaib and Jarboui (2016) reported that CEOs were more likely to engage in REM by reducing research and development (R\&D) expenses in their early years of service than in their year of retirement. Furthermore, Cho, Choi, and Kwon (2019) found a positive and significant link between CEOs' tenure and REM among Korean listed companies from 2000 to 2015.

Cheng and Leung (2012) found that firms led by a well-reputed chairperson with a longer tenure reported higher-quality earnings. The inconsistency in the results on this issue motivated the current study to provide support to the literature by providing new proof concerning this relationship. The following hypothesis has been formulated based on the above debate on the connection between CEOs' tenure and REM.

$\mathrm{H}^{2}$ : CEOs' tenure is related to REM among Jordanian companies listed on the ASE.

\subsection{CEO Duality}

The CEO is responsible for strategic planning and making policy decisions, whereas the chairman monitors and assesses the directors, including the CEO. The concentration of power occurs in a company due to the joint roles of the chairman of the board and CEO (Sáenz González \& García-Meca, 2014). Therefore, joining the functions of CEO and chairman may result in a lack of proper monitoring (Zouari et al., 2015).

Some studies found that the duality of CEOs led to an increase in EM (Boulila Taktak \& Mbarki, 2014, Xie, Davidson, Dadalt, Davidson III, \& Dadalt, 2003). However, other research highlighted that the duality of CEOs did not affect EM (Lin \& Hwang, 2010). For example, Cornett, McNutt, and Tehran (2009) conducted a significant and negative association between CEO duality and EM (Alzoubi, 2016). Further, Chi, Hung, Cheng, and Lieu (2015) found that CEO duality in family firms increased EM.

Other researchers have also examined this relationship. Chen and Liu (2010), for instance, suggested that liberated Chairmen and CEOs are less susceptible to EM. Zouari et al. (2015) noticed that a dual CEO-Chairman position contributed to the management of earnings, especially when the CEO-Chair held a large proportion of the equity in the company. Gulzar and Wang (2011) reported a significantly positive association between CEO duality and EM. 
Moreover, Iraya et al. (2015) explored the effect of corporate governance practices on EM among the firms listed on the Nairobi Securities Exchange (NSE) from 2010 to 2012. The study found a positive and significant link between CEO duality and EM. Moreover, Baker et al. (2018) showed that organisations with CEO duality tended to have higher EM and that position independence prevented the use of EM. The study by Triki Damak (2018) shown a significant and positive connection between CEO duality and EM.

Alsraheen and Saleh (2017) investigated Jordanian service firms in 2015 and reported a positive and significant link between CEO duality and EM. Veprauskaite and Adams (2013) provided evidence of the negative impact of CEO duality on a company's financial performance, which might create a greater need to utilise EM. Yasser and Mamun (2015) found that CEO duality tended to increase transparency of the firm disclosure as well as monitoring and control efficiently. Anderson et al. (2003) reported that the actual quality of earnings was positively linked to the complete splitting of the Chairman and CEO positions.

However, Khalil and Ozkan (2016) found that CEO duality did not lead to reduced earnings manipulation. Moreover, Kamran and Shahm (2014) found that CEO duality did not affect EM. Similarly, Veprauskaite and Adams (2013), Jermias and Gani (2014), and Halioui et al. (2016) argued that CEO duality had a negligible impact on EM. Due to the mixed results on CEO duality, the following hypothesis is proposed:

$\mathrm{H}^{3}$ : CEO duality is related to REM among Jordanian companies listed on the ASE.

\subsection{Politically Connected CEOs}

Stewardship and agency theories offer perspectives on political connectedness. The philosophy of stewardship theory, for example by Barney (1990) and Donaldson and Davis (1991), indicates that government executives may have a significant and positive influence on EM (Bona-Sánchez, Pérez-Alemán, \& Santana-Martín, 2014). In contrast, agency theory argues that politically related CEOs may use political resources to serve their interests instead of shareholders' interests. A question emerges as to whether CEO politically relations and the principal-agent dispute are linked to the level of corporate governance, which has gained little attention in recent academic research (You \& $\mathrm{Du}, 2012)$.

Very few studies have investigated the effect of political connection on earnings quality or EM (Chi et al. 2016). For example, Chi et al. (2016) found that companies helmed by politically connected CEOs had substantially higher levels of real EM compared to those led by non-political CEOs. Braam, Nandy, Weitzel, and Lodh (2015) examined the disparities in accrual and REM strategies among firms with and without political connections. They found that politically connected firms were more likely to replace REM strategies with accrual-based EM strategies than were other firms.

In Jordan, Al-Sraheen and Alkhatib (2016) explored the connection between political influence and EM practices among ASE firms for the fiscal year 2013. They found a significant and positive relationship between the power of political connection and EM practices. In Malaysia, Bliss and Gul (2012) reported that political connection led to higher EM and lower earnings efficiency. Also, Al-Dhamari and Ku Ismail (2015) found that investors perceived low-quality earnings in politically connected companies. Some researchers found that firms with links to politicians were more likely than those without links to have better earnings quality (Song et al., 2011). In a recent study on listed companies in Nigeria, Sani, Abdul Latif, and Al-Dhamari (2020) found a significantly positive association between the political connection of the board members and REM. Based on these results, the hypothesis of the study is proposed as follows:

$\mathrm{H}^{4}$ : Politically connected CEOs have a relationship with EM among Jordanian companies listed on the ASE.

\section{Research Design}

\subsection{Sample and Data Collection}

Companies listed on the Amman Stock Exchange are categorised into one of three sectors, namely, financial, industrial, and service sectors, with 96, 48, and 47 firms, respectively as of 2019 (ASE, 2019). Only the industrial and service sectors were chosen for this study, encompassing 570 firm-year observations from 2013 to 2018. This period was chosen because the latest issue of the corporate governance code in Jordan was issued in 2012, and the most recent available data of firms listed on the ASE was for the year 2018. The financial sector was removed from the study sample because the Central Bank of Jordan and the Insurance Commission have different regulations and practices for this sector. Then, the sample was reduced further to exclude firms with missing data and firms without inventory and cost of goods sold. The final sample for this study included 43 industrial firms and 15 service firms, leading to 348 firm-year observations (58 firms multiplied by 6 years). Data for the current study were 
hand-collected from annual reports and company websites to accomplish the objectives of this study.

\subsection{Measurement of Variables}

\subsubsection{Dependent Variable (REM)}

Following Roychowdhury (2006), Zang (2012), Cohen et al. (2008), and Cohen and Zarowin (2010), this study examined the following real activities manipulation: 1) increasing incomes by reducing the overproduction costs for inventory (abnormal production costs) and 2) decreasing discretionary expenditures including R\&D, sales, advertising, and total and administrative expenditures (abnormal discretionary expenses). Following Roychowdhury (2006), this study estimated the normal level of production costs as follows:

PROD $_{\text {it }} /$ Assets $_{\text {it- } 1}=\alpha_{0}+\alpha_{1}$ [1/ $\left.^{\text {Assets }}{ }_{\text {it- }-1}\right]+\beta_{1}$ [Sales $_{\text {it }} /$ Assets $\left._{\text {it- }-1}\right]+\beta_{2}\left[\Delta\right.$ sales $_{\text {it }} /$ Assets $\left._{\text {it }-1}\right]+\beta_{3}\left[\Delta\right.$ sales $_{\text {it- } 1} /$

$$
\text { Asset } \left._{\text {it- } 1}\right]+€_{\text {it }}
$$

Where PROD is the sum of the cost of goods sold in year $t$ and the change in inventory from year $t-1$ to year $t$; Assets $_{i t-1}$ is the total assets in year $t-1$; Sales ${ }_{i t}$ is the net sales in year $t$; and $\Delta$ sales $_{i t}$ is the change in net sales from year $t-1$ to year $t$.

The abnormal production cost level, RMPROD, is measured as an estimated residual of Equation 1. The higher the residual, the larger the overproduction in inventories and the higher the increase in reported revenues is by reducing the cost of sold goods.

Also, following Roychowdhury (2006), this study estimated the normal level of discretionary expenditures using the following equation:

$$
\text { DISEXP }_{\text {it }} / \text { Assets }_{\text {it }-1}=\alpha_{0}+\alpha_{1}\left(1 / \text { Assets }_{\text {it }-1}\right)+\beta_{1}\left(\text { Sales }_{\text {it }-1} / \text { Assets }_{\text {it }-1}\right)+€_{\text {it }}
$$

where DISEXP ${ }_{i t}$ is the sum of selling, general, and administration expenses in year $t$; Assets $_{i t-1}$ is the total assets in year $t-1$; Sales $_{i t}$ is the net sales in year $t$; and $\Delta$ sales $_{i t}$ is the change in net sales from year $t-1$ to year $t$. The abnormal discretionary expenditures are measured as the estimated residuals from the regression. The residuals were multiplied by -1 such that higher values indicate greater amounts of discretionary expenditures deducted by firms to increase reported earnings.

Following Zang (2012), the study computed REM, which is the aggregated measure of real activities manipulation calculated as the abnormal discretionary expenses (RMDISX) multiplied by -1 plus the abnormal production costs (RMPROD).

\subsubsection{Independent and Control Variables}

This subsection describes the measurement of the independent variables of the present study, as shown in Table 1 . The independent variables are CEO characteristics including the CEOs' experience, CEOs' tenure, CEO duality, and politically connected CEOs, while the control variables are firm size, firm age, financial leverage, market-to-book ratio, and sales growth.

\begin{tabular}{|c|c|c|}
\hline Variables & Measurement & References \\
\hline \multicolumn{3}{|l|}{ Independent variables: } \\
\hline CEOs' experience (CEOEXP) & $\begin{array}{l}\text { The number of executive positions } \\
\text { that the CEO had held before } \\
\text { becoming the CEO. }\end{array}$ & $\begin{array}{l}\text { (Troy, Smith, \& Domino, } \\
\text { 2011). }\end{array}$ \\
\hline CEOs' tenure (CEOTEN) & $\begin{array}{l}\text { The number of years of service as } \\
\text { the CEO. }\end{array}$ & $\begin{array}{l}\text { (Francis, Huang, Rajgopal, } \\
\text { \& Zang, 2008; Altarawneh, } \\
\text { Shafie, \& Ishak, 2020). }\end{array}$ \\
\hline CEO duality (CEODTY) & $\begin{array}{l}1 \text { if the CEO and Chairman were } \\
\text { the same persons, and } 0 \text { if } \\
\text { otherwise. }\end{array}$ & $\begin{array}{l}\text { (Plöckinger, Aschauer, } \\
\text { Hiebl, \& Rohatschek, 2016). }\end{array}$ \\
\hline $\begin{array}{l}\text { Politically connected CEOs } \\
\text { (CEOPOL) }\end{array}$ & $\begin{array}{l}1 \text { if the CEO was politically } \\
\text { connected and } 0 \text { if otherwise. }\end{array}$ & (You \& Du, 2012). \\
\hline
\end{tabular}

Table 1. Measurement of variables 


\section{Control variables}

Firm size (FSIZE)

The natural logarithm of total assets.
(Becker et al., 1998; Myers

et al., 2003, Ashbaugh et al., 2003; Nagy, 2005; Abbott et al., 2006).

\begin{tabular}{|c|c|c|}
\hline Firm age (FAGE) & $\begin{array}{l}\text { The number of years since the } \\
\text { establishment of the company. }\end{array}$ & $\begin{array}{l}\text { (Mapitiya, Ajward \& } \\
\text { Seneratne, 2016). }\end{array}$ \\
\hline Financial leverage (FINLEV) & $\begin{array}{l}\text { Measured by dividing long-term } \\
\text { debt by total assets at the end of } \\
\text { the year. }\end{array}$ & (Mao, Qi, \& Zhang, 2017). \\
\hline $\begin{array}{l}\text { Market-to-book ratio } \\
\text { (MBVALUE) }\end{array}$ & $\begin{array}{l}\text { Measured as the market value of } \\
\text { equity at the end of the fiscal year } \\
\text { divided by the book value of } \\
\text { equity at that date. }\end{array}$ & (Zhang \& Aerts, 2015). \\
\hline Sales growth (SGRWTH) & $\begin{array}{l}\text { Annual sales growth (current year } \\
\text { sales - prior year's sales)/prior } \\
\text { year's sales. }\end{array}$ & $\begin{array}{l}\text { (Al-rassas \& Kamardin, } \\
\text { 2017; Absy, Ismail, \& } \\
\text { Chandren, 2019). }\end{array}$ \\
\hline
\end{tabular}

\subsection{Research Model}

This study developed the following regression model and employed the model to fulfil the research objectives:

$$
\begin{aligned}
\text { REM }= & \beta_{0}+\beta_{1} \text { CEOEXP }_{\text {it }}+\beta_{2} \text { CEOTEN }_{\text {it }}+\beta_{3} \text { CEODTY }_{\text {it }}+\beta_{4} \text { CEOPOL }_{\text {it }}+\beta_{5} \text { FSIZE }_{\text {it }}+\beta_{6} \text { FAGE }_{\text {it }}+ \\
& \beta_{7} \text { FINLEV }_{\text {it }}+\beta_{8} \text { MBVALUE }_{\text {it }}+\beta_{9} \text { SGRWTH }_{\text {it }}+\beta_{10} \text { YEARS }_{\text {it }}+\varepsilon_{\text {it }}
\end{aligned}
$$

where REM = real earnings management (Abnormal Production Costs and Abnormal Discretionary Expenses); $i=$ firm; $t=$ year; $\beta_{0}=$ the intercept; $\varepsilon=$ the error term; $\beta_{1}, \beta_{2}, \beta_{3}, \beta_{4} \ldots=$ the coefficients; CEOEXP = CEO's experience; CEOTEN $=$ CEO's tenure CEODTY $=$ CEO duality; $\mathrm{CEOPOL}=$ politically connected CEO; SGRWTH $=$ sales growth; and YEARS = Dummy variable of the study time period.

\section{Results}

\subsection{Descriptive Statistics}

The descriptive statistics of the dependent variables are presented in Table 2, whereas Table 3 presents the descriptive statistics of the independent and control variables.

Table 2. Descriptive Statistics of the dependent variables

\begin{tabular}{lccccc}
\hline Variable & Obs & Mean & Std.Dev. & Min & Max \\
\hline RPROD & 348 & 0.000 & 0.122 & -0.662 & 0.383 \\
\hline RDISEXP & 348 & 0.000 & 0.088 & -0.33 & 0.67 \\
\hline REM & 348 & 0.000 & 0.175 & -0.781 & 0.452 \\
\hline
\end{tabular}

Table 2 shows that the mean value of REM is 0.000 , which is too close to the mean of 0.004 reported by (Huang and Roychowdhury, 2019), with minimum value of -0.781 and maximum value of 0.452 . In addition, the mean value of PROD is 0.000 , which is too close to the mean of 0.001 reported by (Huang and Roychowdhury, 2019), with minimum value of -0.662 and maximum value of 0.383 . Moreover, the mean value of DISEXP is 0.000 , which is too close to the mean of 0.004 reported by (Huang and Roychowdhury, 2019), with minimum value of -0.33 and maximum value of 0.67 . 
Table 3. Descriptive Statistics of the independent and control variables

\begin{tabular}{lcllcc}
\hline Variable & Obs & Mean & Std.Dev. & Min & Max \\
\hline CEOEXP & 348 & 0.98 & 1.145 & 0 & 4 \\
\hline CEOTEN & 348 & 9.764 & 9.257 & 1 & 54 \\
\hline CEODTY & 348 & 0.118 & 0.323 & 0 & 1 \\
\hline CEOPOL & 348 & 0.069 & 0.254 & 0 & 1 \\
\hline FSIZE & 348 & 17.144 & 1.411 & 13.14 & 20.904 \\
\hline FAGE & 348 & 30.399 & 17.427 & 5 & 81 \\
\hline LogFAGE & 348 & 1.406 & 0.269 & 0.699 & 1.908 \\
\hline FINLEV & 348 & 0.864 & 4.112 & 0.004 & 48.743 \\
\hline MBVALUE & 348 & 1.295 & 1.382 & 0.133 & 14.088 \\
\hline SGRWTH & 348 & -0.028 & 0.265 & -0.618 & 0.775 \\
\hline
\end{tabular}

Table 3 shows that the maximum and minimum numbers of executive positions that the CEOs in this sample held before becoming the CEO are 4 and 0 positions, respectively, whereas the mean for this variable is 0.98 . This result is comparatively greater than the mean of 0.718 reported by Zouari, Lakhal and Nekhili (2015). Also, the maximum number of years of service as the CEO for this sample is 54 years, and the minimum is 1 year, while the mean is 9.764. This value was higher than the mean of 8.725 presented by Sun, Lan, \& Liu (2014). Next, the table shows that the maximum value for the CEO duality variable is 1 and the minimum is 0 , as it is a dummy variable measured by 1 if the Chairman and CEO are the same person and 0 if otherwise. The mean for this variable is 0.118 , which means that $12 \%$ of the sample firms combined the CEO and Chairman positions. This result is relatively close to the results of Alqatamin (2016) in Jordan with a mean of 0.208. Finally, the politically connected CEO variable is a dummy variable and measured by 1 if the CEO was politically connected and 0 if otherwise. The maximum and minimum values for this variable are 1 and 0 , respectively, while the mean is 0.069 . This value is lower than the mean of 0.228 presented by Chi, Liao, \& Chen (2016) in China. Lastly, the table also presented the descriptive statistics of the control variables, namely, FSIZE, FAGE, LEV, MTB, and SGRWTH. The mean values are for these control variables are $17.144,30.399,0.864,1.295$, and -0.028 , respectively. The maximum value for firm size is 20.904 , the minimum value is 13.14 . Regarding firm age, the maximum is 81 years, the minimum is 5 years. Then, the firm age values were logged in the regression in this study. Next, the maximum and minimum values for the market to book ratio are 14.088 and 0.133 . Finally, the maximum and minimum values for sales growth are $0.775,-0.618$, and 0.265 , respectively.

\subsection{Empirical Results}

This study examined whether the model used to analyse the effect of CEO characteristics on REM activities had an econometric issue before the experiment was carried out. The problem of multicollinearity exists when the correlations between the independent variables are greater than 0.90 (Hair et al., 2010; Tabachnick \& Fidell, 2007). The current study used Pearson's correlation (correlation matrix) to identify the multicollinearity issues. Table 4 shows that the highest correlation is between firm size and leverage, with a coefficient of 37 per cent. Therefore, the multicollinearity problem did not exist between the dataset used in this study's model.

Table 4. Matrix of correlations

\begin{tabular}{|c|c|c|c|c|c|c|c|c|c|c|}
\hline Variables & (1) & $(2)$ & (3) & (4) & $(5)$ & $(6)$ & (7) & $(8)$ & (9) & $(10)$ \\
\hline (1) REM & 1 & & & & & & & & & \\
\hline (2) CEOEXP & 0.102 & 1 & & & & & & & & \\
\hline (3) CEOTEN & -0.021 & -0.209 & 1 & & & & & & & \\
\hline (4) CEODTY & -0.198 & 0.053 & 0.076 & 1 & & & & & & \\
\hline (5) CEOPOL & 0.099 & -0.174 & -0.010 & 0.182 & 1 & & & & & \\
\hline (6) FSIZE & -0.054 & 0.085 & 0.141 & -0.134 & -0.128 & 1 & & & & \\
\hline (7) LogFAGE & 0.041 & -0.067 & 0.238 & -0.135 & 0.078 & -0.135 & 1 & & & \\
\hline (8) LEV & 0.084 & 0.006 & -0.071 & -0.219 & 0.026 & 0.371 & 0.077 & 1 & & \\
\hline (9) MTB & -0.269 & 0.065 & -0.052 & 0.048 & -0.078 & 0.287 & 0.043 & 0.255 & 1 & \\
\hline (10) SGRWTH & -0.104 & 0.151 & -0.055 & -0.086 & -0.160 & 0.141 & -0.085 & 0.091 & 0.191 & 1 \\
\hline
\end{tabular}


The robust standard error regression results are shown in Table 5. The $R^{2}$ value for the model is comparatively small at 0.168 as compared to the $R^{2}$ of 0.682 reported by AlQadasi and Abidin (2018) in Jordan, but higher than the R2 of 0.071 reported by Ocak and Can (2018) using Turkish listed firms. This result indicated the validity of the study model. According to the results presented in the table, CEO's experience (CEOEXP) was shown to have a significantly positive relationship on REM at the 1 per cent level of significance $(t=3.40, p<0.01)$. This result shows that the CEOs with vast experience managed earnings for their self-interest. The CEOs used the ability gained over their years of service as executives to intervene and adjust the accounting information disclosed in the financial reports. This result is in line with the expectation of hypothesis1. As well, the result is consistent with the viewpoint of upper echelons theory that more experienced CEOs would be more inclined to take risks to engage in REM than less experienced ones. In addition, this result is in line with the previous studies, such as Kouaib and Jarboui (2016a), Yang (2010), and Baatwah et al. (2015).

As shown in Table 5, CEOs' tenure was not associated with REM $(t=0.59, p>0.10)$. This result implies that CEOs' tenure did not affect REM among Jordanian firms. The possible reason behind the result is the years of service as a CEO did not affect the CEOs' decisions to manipulate their companies' earnings via REM practices. This result is not consistent with the expectation of hypothesis 2. In addition, this result is in line with Sun, Lan, and Liu, (2014), which found that CEOs' tenure did not affect REM.

Table 5 also shows a significantly negative association between CEO duality and REM $(t=-3.84, p<0.01)$. This result shows that when the CEO and chairman were the same person, the REM practices were reduced. This result is consistent with stewardship theory, in which both positions in combination enhances the decision-making process and enables the CEO to lead the board more efficiently in the pursuit of the goals of the organisation with minimum board interference. In addition, this result consistent with the expectation of hypothesis 3. Moreover, this result is congruent with Yasser and Mamun (2015). Furthermore, Table 5 reveals a significantly positive association between politically connected CEOs and REM $(t=2.30, p<0.05)$. This result is not surprising, as CEOs are more likely to manipulate reported earnings through REM when they are politically connected. This result is consistent with the expectation of hypothesis 4 . This finding is in line with the assumption of stewardship theory that political directors can positively influence EM, which is in line with the previous literature, for instance, Chi et al. (2016) and Al-Sraheen and Alkhatib (2016).

Concerning the control variables, the relation between firm size and REM was insignificant and negative. This result means that the size of the firms did not affect the engagement of the CEOs in real EM. Moreover, firm age was not associated with REM. Also, Table 5 indicates as positive association between leverage and REM. However, MTB and REM had a significantly negative association. Finally, Table 5 shows the existence of a significantly negative relationship between sales growth and REM.

Table 5. Linear regression

\begin{tabular}{|c|c|c|c|}
\hline REM & Coef. & t-value & p-value \\
\hline CEOEXP & 0.028 & 3.40 & $0.001 * * *$ \\
\hline CEOTEN & 0.001 & 0.59 & 0.553 \\
\hline CEODTY & -0.114 & -3.84 & $0.000 * * *$ \\
\hline CEOPOL & 0.084 & 2.30 & $0.022 * *$ \\
\hline FSIZE & -0.006 & -0.76 & 0.451 \\
\hline LogFAGE & 0.003 & 0.07 & 0.944 \\
\hline LEV & 0.102 & 2.36 & $0.019 * *$ \\
\hline MTB & -0.046 & -4.90 & $0.000 * * *$ \\
\hline SGRWTH & -0.061 & -1.69 & $0.091 *$ \\
\hline Constant & 0.102 & 0.74 & 0.462 \\
\hline Year effect & & Yes & \\
\hline Number of obs & $=$ & 348 & \\
\hline R-squared & $=$ & 0.168 & \\
\hline Prob > F & $=$ & 0.000 & \\
\hline
\end{tabular}

Note: $\mathrm{REM}=$ Real Earning Management, $\mathrm{CEOEXP}=\mathrm{CEO}$ experience, $\mathrm{CEOTEN}=\mathrm{CEO}$ tenure, $\mathrm{CEODTY}=\mathrm{CEO}$ duality, $\mathrm{CEOPOL}=\mathrm{CEO}$ politically connected, FSIZE $=$ firm size, LogFAGE $=$ firm age (logged), LEV = leverage, MTB = market to book value, SGRWTH = sales growth . 


\section{Conclusion}

The objective of the current study is to assess the effect of the characteristics of CEOs on REM in Jordan-listed firms from 2013 to 2018. The overall results show that the interactions of CEO characteristics with REM were positive and significant. The regression also reveals a significantly negative association between CEO duality and REM. The findings also indicate that politically connected CEOs were related to REM with a positive and significant relationship. Meanwhile, the relationship between CEOs' tenure and REM was not significant.

In view of the influence of CEO characteristics on REM in Jordan and other developing countries, the study would concern politicians, regulators, and academics. Nonetheless, the results of this study are focused solely on non-financial firms and further studies should focus on the financial sector, which plays an increasingly crucial role as the Middle East and North Africa (MENA) market liberaliser for the emerging economies, particularly in Jordan.

In addition, the current study contributes to the literature as well as to the knowledge, by giving an investigation of characteristics of the CEO and REM in Jordan. The current study also will provide avenue for the upcoming scholars in conducting studies like this study in regards to other characteristics of the CEO with REM. Moreover, this paper will help the future scholars to assess the features that affect the EM. Likewise, this paper offers evidence of the relationship between CEO experience, tenure, duality and political connection and REM in Jordan. Furthermore, the paper is significant to the investors and shareholders because this paper highlights the features that affect EM.

Otherwise, the current study has numerous limitations. Firstly, REM may be influenced by another aspects and features that are not involved in the current study as it emphasis only on four CEO characteristics. Secondly, this study finding might be not valid to the other emerging countries that applied different regulations. Such confines expose outlooks for forthcoming studies on this matter that might be assumed in the future, for instance, to explore another feature that would affect REM, such as CEO honorific title, gender, power, ethnicity, and founder. Finally, in spite of all applied exertions that occupied by the current study to classify the REM, it is thinkable for upcoming studies to practice all explanations and categories in classifying REM in Jordan to observe the effects of REM based on dissimilar explanations.

\section{References}

Abbott, L. J., Parker, S., \& Peters, G. F. (2006). Earnings management, litigation risk, and asymmetric audit fee responses. Auditing: A Journal of Practice \& Theory, 25(1), 85-98.

Al-Absy, M. S. M., Ismail, K. N. I. K., \& Chandren, S. (2019). Corporate Governance Mechanisms, Whistle-Blowing Policy and Real Earnings Management. International Journal of Financial Research, 10(6).

Al-Dhamari, R., \& Ismail, K. N. I. K. (2015). Cash holdings, political connections, and earnings quality. International Journal of Managerial Finance.

Ali, A., \& Zhang, W. (2015). CEO tenure and earnings management. Journal of Accounting and Economics, 59(1), 60-79. https://doi.org/10.1016/j.jacceco.2014.11.004

Al-Rassas, A. H., \& Kamardin, H. (2015). Directors' independence, internal audit function, ownership concentration and earnings quality in Malaysia. Asian Social Science, 11(15), 244-256.

Al-Sraheen, D. A. D., \& Alkhatib, K. (2016). Proposing a model for limiting earning management practices: The case of Jordanian listed firms. Corporate Board: Role, Duties and Composition, 12(3), 81-84.

Altarawneh, M., Shafie, R., \& Ishak, R. (2020). CEO Characteristics: A Literature Review and Future Directions. Academy of Strategic Management Journal, 19(1), 1-10.

Altarawneh, M., Shafie, R., \& Ishak, R. (2020). Chief Executive Officer Characteristics and Financial Restatements in Malaysia. International Journal of Financial Research, 11(2), 173-186.

Alzoubi, E. S. S. (2016). Audit quality and earnings management: evidence from Jordan. Journal of Applied Accounting Research.

Anderson, R. C., Mansi, S. A., \& Reeb, D. M. (2004). Board characteristics, accounting report integrity, and the cost of debt. Journal of Accounting and Economics, 37(3), 315-342.

Ashbaugh, H., \& Warfield, T. D. (2003). Audits as a corporate governance mechanism: Evidence from the German market. Journal of International Accounting Research, 2(1), 1-21.

Barney, J. B. (1990). The debate between traditional management theory and organizational economics: substantive differences or intergroup conflict?. Academy of Management Review, 15(3), 382-393. 
Bermejo-Sánchez, M., Rodríguez-Ariza, L., \& Martínez-Ferrero, J. (2015). The link between earnings management and corporate performance: evidence from family firms. International Journal of Entrepreneurship and Small Business, 25(1), 106-124.

Bliss, M. A., \& Gul, F. A. (2012). Political connection and cost of debt: Some Malaysian evidence. Journal of Banking \& Finance, 36(5), 1520-1527.

Bona-Sánchez, C., Pérez-Alemán, J., \& Santana-Martín, D. J. (2014). Politically Connected Firms and Earnings Informativeness in the Controlling versus Minority Shareholders Context: E uropean Evidence. Corporate Governance: An International Review, 22(4), 330-346.

Bouaziz, D., Salhi, B., \& Jarboui, A. (2020). CEO characteristics and earnings management: empirical evidence from France. Journal of Financial Reporting and Accounting.

Braam, G., Nandy, M., Weitzel, U., \& Lodh, S. (2015). Accrual-based and real earnings management and political connections. The International Journal of Accounting, 50(2), 111-141.

Chen, K., \& Liu, J.-L. (2010). Earnings management, CEO domination, and growth opportunities: Evidence from Taiwan. International Journal of Public Information Systems, 6(1).

Cheng, L. T. W., \& Leung, T. Y. (2012). The effects of management demography on auditor choice and earnings quality: Evidence from China. Review of Pacific Basin Financial Markets and Policies, 15(02), 1150009.

Chi, C. W., Hung, K., Cheng, H. W., \& Lieu, P. T. (2015). Family firms and earnings management in Taiwan: Influence of corporate governance. International Review of Economics \& Finance, 36, 88-98.

Chi, J., Liao, J., \& Chen, X. (2016). Politically connected CEOs and earnings management: evidence from China. Journal of the Asia Pacific Economy, 21(3), 397-417.

Cho, H., Choi, S., \& Kwon, D. H. (2019). Employee tenure and earnings management through real activities manipulation. Asia-Pacific Journal of Accounting \& Economics, 1-24.

Chou, Y.-Y., \& Chan, M.-L. (2018). The impact of CEO characteristics on real earnings management: Evidence from the US banking industry. Journal of Applied Finance and Banking, 8(2), 17-44.

Cohen, D. A., \& Zarowin, P. (2010). Accrual-based and real earnings management activities around seasoned equity offerings. Journal of Accounting and Economics, 50(1), 2-19.

Cohen, D. A., Dey, A., \& Lys, T. Z. (2008). Real and accrual-based earnings management in the pre-and post-Sarbanes-Oxley periods. The Accounting Review, 83(3), 757-787.

Custódio, C., \& Metzger, D. (2014). Financial expert CEOs: CEO 's work experience and firm 's financial policies. Journal of Financial Economics, 114(1), 125-154.

Dea'a Al-Deen, O. A., \& Isam, H. S. (2017, October). Does the Monitoring Mechanisms Considered as Dilemma against the Practices of Earnings Management. International Business Research, 10(10), 39-44.

Di Meo, F. (2014). Overinvestment, subsequent earnings management, and CEO tenure. Spanish Journal of Finance and Accounting/Revista Española de Financiación y Contabilidad, 43(3), 217-240.

Donaldson, L., \& Davis, J. H. (1991). Stewardship theory or agency theory: CEO governance and shareholder returns. Australian Journal of Management, 16(1), 49-64.

Francis, J., Huang, A. H., Rajgopal, S., \& Zang, A. Y. (2008). CEO reputation and earnings quality. Contemporary Accounting Research, 25(1), 109-147.

García Osma, B., Gill de Albornoz Noguer, B., \& Gisbert Clemente, A. (2005). La investigación sobre earnings management. Revista Española de Financiación y Contabilidad, 34(127), 1001-1034.

González, J. S., \& García-Meca, E. (2014). Does corporate governance influence earnings management in Latin American markets?. Journal of Business Ethics, 121(3), 419-440.

Gounopoulos, D., \& Pham, H. (2018). Financial expert CEOs and earnings management around initial public offerings. The International Journal of Accounting, 53(2), 102-117.

Gounopoulos, D., Loukopoulos, G., \& Loukopoulos, P. (2019). Do financial expert CEOs matter for newly public firms?. Financial Management Association 2019.

Greve, H. R., Palmer, D., \& Pozner, J. (2010). Organizations gone wild: The causes, processes, and consequences of organizational misconduct. The Academy of Management Annals, 4(1), 53-107. 
Gulzar, M. A. (2011). Corporate governance characteristics and earnings management: Empirical evidence from Chinese listed firms. International Journal of Accounting and Financial Reporting, 1(1), 133-151.

Hair, J. F., Black, W. C, Babin, B. J., \& Anderson, R. (2010). Multivariate Data Analysis, 7.

Halioui, K., Neifar, S., \& Abdelaziz, F. B. (2016). Corporate governance, CEO compensation and tax aggressiveness. Review of Accounting and Finance.

Hambrick, D. C. (2007). Upper echelons theory: An update. Academy of Management Briarcliff Manor, NY.

Hitt, M. A., \& Tyler, B. B. (1991). Strategic decision models: Integrating different perspectives. Strategic Management Journal, 12(5), 327-351.

Hoechle, D. (2007). Robust standard errors for panel regressions with cross-sectional dependence. The Stata Journal, 7(3), 281-312.

Hu, N., Hao, Q., Liu, L., \& Yao, L. J. (2015). Managerial tenure and earnings management. International Journal of Accounting \& Information Management.

Hu, N., Huang, R., Li, X., \& Liu, L. (2017). The impact of CEOs' accounting backgrounds on earnings management and conservatism. Journal of Centrum Cathedra.

Idris, M., Siam, Y. A., \& Nassar, M. (2018). Board independence, earnings management and the moderating effect of family ownership in Jordan. Management \& Marketing, 13(2), 985-994.

Jallow, K., Leventis, S., \& Dimitropoulos, P. (2012). The role of corporate governance in earnings management: experience from US banks. Journal of Applied Accounting Research.

Jensen, M. C. (1986). Agency costs of free cash flow, corporate finance, and takeovers. The American Economic Review, 76(2), 323-329.

Jermias, J., \& Gani, L. (2014). The impact of board capital and board characteristics on firm performance. The British Accounting Review, 46(2), 135-153.

Jiang, F., Zhu, B., \& Huang, J. (2013). CEO's financial experience and earnings management. Journal of Multinational Financial Management, 23(3), 134-145.

Kamran, K., \& Shah, A. (2014). The impact of corporate governance and ownership structure on earnings management practices: Evidence from listed companies in Pakistan. The Lahore Journal of Economics, 19(2), 27-70.

Khalil, M., \& Ozkan, A. (2016). Board independence, audit quality and earnings management: Evidence from Egypt. Journal of Emerging Market Finance, 15(1), 84-118.

Kouaib, A., \& Jarboui, A. (2016). Real earnings management in innovative firms: Does CEO profile make a difference?. Journal of Behavioral and Experimental Finance, 12, 40-54.

Latif, R. A., \& Al-Dhamari, R. A. (2020). CEO discretion, political connection and real earnings management in Nigeria. Management Research Review.

Leventis, S., Dimitropoulos, P. E., \& Anandarajan, A. (2012). Signalling by banks using loan loss provisions: the case of the European Union. Journal of Economic Studies.

Lin, J. W., \& Hwang, M. I. (2010). Audit quality, corporate governance, and earnings management: A meta analysis. International Journal of Auditing, 14(1), 57-77.

Liu, J. (2012). Board monitoring, management contracting and earnings management: an evidence from ASX listed companies. International Journal of Economics and Finance, 4(12), 121-136.

Mao, J., Qi, B., \& Zhang, G. (2017). The Scale and Scope of the Client Portfolio and Audit Pricing at the Individual Auditor Level: Evidence from China. SSRN.

Mapitiya, G. S., Ajward, A. R., \& Senaratne, S. (2016). Ownership concentration and degree of compliance with corporate governance best practices of public listed companies in Sri Lanka. NSBM Journal of Management, $1(1)$.

Matsunaga, S. R., \& Yeung, P. E. (2008). Evidence on the impact of a CEO's financial experience on the quality of the firm's financial reports and disclosures. AAA.

Nagy, A. L. (2005). Mandatory audit firm turnover, financial reporting quality, and client bargaining power: The 
case of Arthur Andersen. Accounting Horizons, 19(2), 51-68.

Plöckinger, M., Aschauer, E., Hiebl, M. R. W., \& Rohatschek, R. (2016). The influence of individual executives on corporate financial reporting: A review and outlook from the perspective of upper echelons theory. Journal of Accounting Literature, 37, 55-75.

Ramadan, I. Z. (2015). Does ownership structure affect Jordanian companies' tendency to practice earnings management?. Asian Journal of Finance \& Accounting, 7(2), 281-291.

Ran, G., Fang, Q., Luo, S., \& Chan, K. C. (2015). Supervisory board characteristics and accounting information quality: Evidence from China. International Review of Economics \& Finance, 37, 18-32.

Roychowdhury, S. (2006). Earnings management through real activities manipulation. Journal of Accounting and Economics, 42(3), 335-370.

Saleem, F., Alifiah, M. N., \& Tahir, M. S. (2016). The effectiveness of monitoring mechanisms for constraining earnings management: A literature survey for a conceptual framework. International Journal of Economics and Financial Issues, 6(3S), 209-214.

Schrand, C. M., \& Zechman, S. L. C. (2012). Executive overconfidence and the slippery slope to financial misreporting. Journal of Accounting and Economics, 53(1-2), 311-329. https://doi.org/10.1016/j.jacceco.2011.09.001

Shbeilat, M. K. (2013). The Jordanian Corporate Governance Code: A study of institutional investors' perception of the reliability of the audit report and the audit expectation gap. Thesis, Australian Catholic University.

Sun, J., Lan, G., \& Liu, G. (2014). Independent audit committee characteristics and real earnings management. Managerial Auditing Journal.

Tabachnick, B. G., Fidell, L. S., \& Ullman, J. B. (2007). Using multivariate statistics (Vol. 5). Pearson Boston, MA.

Taktak, N. B., \& Mbarki, I. (2014). Board characteristics, external auditing quality and earnings management. Journal of Accounting in Emerging Economies.

Troy, C., Smith, K. G., \& Domino, M. A. (2011). CEO demographics and accounting fraud: Who is more likely to rationalize illegal acts?. Strategic Organization, 9(4), 259-282.

Veprauskaitè, E., \& Adams, M. (2013). Do powerful chief executives influence the financial performance of UK firms?. The British Accounting Review, 45(3), 229-241.

Yasser, Q. R., \& Al Mamun, A. (2015). The impact of CEO duality attributes on earnings management in the East. Corporate Governance.

You, J., \& Du, G. (2012). Are political connections a blessing or a curse? Evidence from CEO turnover in China. Corporate Governance: An International Review, 20(2), 179-194.

Zahra, S. A. (2005). Entrepreneurial risk taking in family firms. Family Business Review, 18(1), 23-40.

Zang, A. Y. (2012). Evidence on the trade-off between real activities manipulation and accrual-based earnings management. The Accounting Review, 87(2), 675-703.

Zhang, S., \& Aerts, W. (2015). Management's performance justification and failure to meet earnings thresholds. Accounting and Business Research, 45(6-7), 841-868.

Zhao, Q., Gao, J., \& Wang, S. (2016). Literature review on the relationship between managerial ability and real earnings management. In 2016 13th International Conference on Service Systems and Service Management (ICSSSM) (pp. 1-4). IEEE.

Zouari, Z., Lakhal, F., \& Nekhili, M. (2012). Do CEO's characteristics affect earnings management? Evidence from France. Evidence from France, June 11, 2012.

Zureigat, B. N., Fadzil, F. H., \& Ismail, S. S. S. (2014). The Role of Foreign, Family Ownership and Audit Committee in Evaluating the Company as a Going Concern: Evidence from Jordan. International Journal of Accounting and Financial Reporting, 4(2), 329. 